\title{
En flaske med ukjent innhold
}
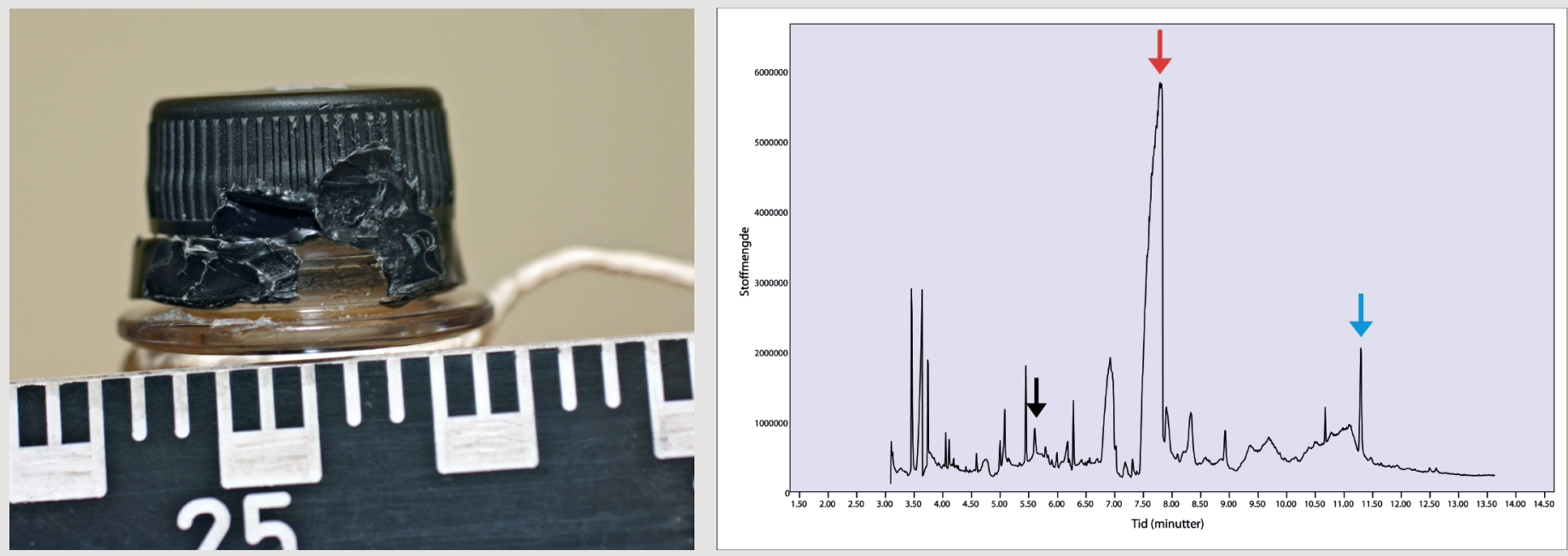

Foto Jim Løvås, Sør-Trøndelag politidistrikt

En ung mann kontaktet legevakten med ubehag i munnhule og svelg etter å ha drukket Coca-Cola Zero. Flasken hadde han selv kjøpt i butikken. Innholdet smakte salt og «kjemisk», og det sved i munn og hals. Da han oppdaget at forseglingsringen på korken var brutt og tilsynelatende forsøkt smeltet sammen igjen, kontaktet han legevakt og politi.

Vi bisto politiet med en gasskromatografisk-massespektrometrisk (GCMS) analyse av flaskens innhold. Metoden, som også brukes i toksikologiske analyser ved rettslige obduksjoner, består i at stoffet varmes opp mens det transporteres med inert gass gjennom et rør (kolonne), der molekyler separeres etter kokepunkt og polaritet. Stoffer med lavt kokepunkt vandrer raskere gjennom kolonnen enn stoffer med høyt kokepunkt. Etter hvert som enkeltstoffene kommer ut av kolonnen, registreres de som kromatografiske topper. Deretter fragmenteres og ioniseres stoffene i et vakuumkammer, og ionene som oppstår akselereres, filtreres og registreres i et massespektrometer. Hvert stoff danner sitt unike massespekter, et slags fingeravtrykk, som kan sammenliknes med et referansebibliotek av ca. 200000 kjente forbindelser for å identifisere ukjente stoffer. Vi analyserte også en normal brusflaske av samme merke for sammenlikning.

I flaskens innhold fant vi blant annet koffein (blå pil) og smaksstoffet limonén (svart pil), som forventet. Toppen vist med den røde pilen var imidlertid uventet. Stoffet ble identifisert og bekreftet som hydroksymetylfurfural (IUPAC-navn: 5-(hydroxymethyl)-2-furaldehyde). Dette finnes naturlig i blant annet kaffe og tørket frukt og dannes også under varmebehandling av sukkerholdig mat. Høye konsentrasjoner kan tyde på overdreven varmebehandling eller for lang lagringstid. Stoffet har en bitter smak og er lokalirriterende, men ikke spesielt toksisk.

Pasientens ubehag gikk over i løpet av noen timer. Det dukket ikke opp andre tilfeller, og man fant ikke flere slike flasker i butikkens hyller.

\section{Andreas Austgulen Westin} andreas.westin@legemidler.no Wenche Rødseth Brede

Avdeling for klinisk farmakologi

St. Olavs hospital

Pasienten har gitt samtykke til at artikkelen blir publisert.

Andreas Austgulen Westin (f. 1977) er lege i spesialisering ved Avdeling for klinisk farmakologi.

Ingen oppgitte interessekonflikter.

Wenche Rødseth Brede (f. 1951) er m.sc. og spesialbioingeniør ved Avdeling for klinisk farmakologi.

Ingen oppgitte interessekonflikter.

Mottatt 21.3. 2011, første revisjon innsendt 15.6. 2011, godkjent 7.7. 2011. Medisinsk redaktør Erlend T. Aasheim. 